\title{
Studies on Flocculating Activity of Bioflocculant from Closed Drainage System (CDS) and Its Application in Reactive Dye Removal
}

\author{
Yasaman Sanayei (Corresponding author), Norli Ismail, Tjoon Tow Teng \& Norhashimah Morad \\ School of Industrial Technology, Environmental Technology Division \\ Universiti Sains Malaysia, Pulau Pinang 11800, Malaysia \\ E-mail: yasaman_sanayei@yahoo.com
}

\begin{abstract}
Technological production processes of organic dyes soluble in water, as well as the processes for their application in textile industries, may heavily pollute natural waters, particularly from the point of view of their pronounced colored wastewaters. Reactive dyes are prominent among numerous groups of water-soluble dyes. The bioflocculant was effective in flocculating a kind of reactive soluble dyes (Cibacron yellow FN_2R) in aqueous solution. A bioflocculantproducing bacterium were isolated from wastewater and sediments of Close Drainage Systems (CDS) located at the Prai industrial area.. Compared with conventional chemical flocculants, bioflocculants are biodegradable and nontoxic, and produce no secondary pollution. Sphingomonas paucimobilis was found to produce a bioflocculant with high flocculating activity for Kaolin suspension and water-soluble dyes. The best temperature flocculation performance was $35^{\circ} \mathrm{C}$ and shaking speed of $160 \mathrm{rpm}$. The highest flocculating efficiency achieved for Kaolin suspension was $98.4 \%$ at $35^{\circ} \mathrm{C}$ after 48 hours cultivation. Various culture temperatures were tested between 2 hours in order to investigate their effect on the bioflocculant production when the culture temperature was $35^{\circ} \mathrm{C}$ which the flocculating activity of Sphingomonas paucimobilis was up to $98.4 \%$. It was found that, flocculating rate depends on time and temperatures. Determination flocculating activity was shown Sphingomonas paucimobilis is biodegradable and increase in number of bacteria during the time will confirm that. This study was conducted to biologically treat wastewater discharged from the textile industry using sequencing batch reactor (SBR) technology biological flocculation on COD removal and effects of solids detention times and MLVSS on EPS production.
\end{abstract}

Keywords: Bioflocculant, Reactive dye, Sphingomonas paucimobilis, Flocculating activity

\section{Introduction}

Rapid development of industrialization and human activities has lead to increase the discharge of waste and wastewater containing organic and inorganic pollutants. Bioflocculant is a kind of biodegradable macromolecular flocculants created by microorganisms. Because of their biodegradability, harmlessness and lack of secondary pollution bioflocculants have gained much wider attention and research to date (Li Y., 1999). Flocculation is an essential process in the treatment of wastewater, tap water production and dredging or downstream processing techniques in a variety of industrial fields (Fujita M., 2000). Dye wastewaters are recognized as one of the difficult pollutants to be treated. They are discharged to the environment from a wide variety of sources, including textiles, printing, dyeing, dyestuff manufacturing, and food plants (Lee C., 2008). The annual worldwide production of dyes is approximated at 800,000 tones and about $50 \%$ of these are azo-dyes. Hence, the treatment of such wastewaters is quickly becoming a matter of great concern and it is urgent to develop sound and cost-effective treatment technologies in order to comply with environmental regulations (M. Zhou, 2007) and (A.S. Özcan, 2005). Coagulation and flocculation have their place among the conventional processes that are frequently cited for treating dye-containing effluents (W. Zhu, 2001), (D. Georgiou, 2003) and (C. Allegre, 2004). The main advantage of coagulation and flocculation is the decolorize the waste stream by the removal of dye molecules from the dye bath effluents, and not by a partial decomposition of the dye, which can lead to even more harmful and toxic aromatic compounds (V. Golob, 2005).

The removal of dyes from wastewater presents a formidable challenge, as most dyes are completely soluble in aqueous solutions. Some cationic flocculants, such as the cationic polyaluminum chloride and polyacrylamide have been found to be effective in dye removal, and charge neutralization between anionic sulfuric groups in the dye molecules and cationic flocculants molecules have been found to play an important role in the flocculation process (J.H. Choi, 2001) and (B.H. Tan, 2000). At present, several methods have been developed to treat dye wastewater. Physicochemical treatments such as coagulation/flocculation, flotation, membrane processes or activated carbon adsorption are common 
practices, but they are quite inefficient and result in a phase transfer of pollutants, leaving the problem unsolved. On the other hand, single biological treatments, the most economical and environmentally friendly ones, are not a suitable alternative when working with toxic and/or non-biodegradable wastewaters. In fact, most of disposed dyes are of nonbiodegradable nature and standard biological treatment of their colored effluents is not effective (Garcia-Montano J., 2006). The application of SBR to color removal is rather a new approach compared to anaerobic-aerobic sequential treatment (Kapdan, I. K., 2005). Recent research has focused on the use of bio-coagulants and bio-flocculants (J. Roussy, 2005). This paper aims to examine the best culture conditions for the production of a bioflocculant by Sphingomonas paucimobilis using dye wastewaters as feeding substrate. The reactive dye (Cibacron yellow FN_2R) was treated by sequencing batch reactor, where the dye concentration influenced the system.

\section{Materials and methods}

\subsection{Nomenclature}

CDS: close drainage systems

COD: chemical oxygen demand

EPS: exocellular biopolymers substance

HRT: hydraulic retention time

MLVSS: mixed liquor suspended solids

OD: optical density

PGA: Polyglutamic Acid

$\mathrm{R}$ : reactor

SBR: sequencing batch reactor

\subsection{Preparation of biopolymer flocculants}

One loop, full of bio-flocculants producing bacteria isolated from Closed Drainage System, (CDS) located at the Prai area and grown on slant agar at $35^{\circ} \mathrm{C}$ for 2 days in oven, (K. Kakii, 1986) and (T. Endo, 1976).

\subsection{Bioflocculant-producing medium and culture conditions}

The composition of the basic culture medium for the production of bioflocculant Compositions of medium were as follows: $20(\mathrm{~g} / \mathrm{L})$ glucose, $0.5(\mathrm{~g} / \mathrm{L})$ yeast extract, $50(\mathrm{~g} / \mathrm{L})$ L-glutamic acid and $0.5(\mathrm{~g} / \mathrm{L})$ magnesium sulphate heptahydrate $(\mathrm{MgSO} 4.7 \mathrm{H} 2 \mathrm{O})$ and the medium was adjusted to $\mathrm{pH}$ 7.0.The medium was solidified by addition of $15 \mathrm{~g}$ bacteriological agar powder in $1.0 \mathrm{~L}$ deionized water. Polyglutamic Acid (PGA) was used as a medium for cultivation of bioflocculant producing bacteria. After autoclaving and inoculating the medium, the bacteria were cultured in 250 $\mathrm{mL}$ conical flasks on a rotary shaker at $160 \mathrm{rpm}$ and $35^{\circ} \mathrm{C}$ for 2 days. Samples were taken at various time intervals to determine the $\mathrm{pH}$, flocculating activity. At the same conditions used to culture the single colonies that were selected in PGA broth to measure their flocculating activities.

\subsection{Flocculating Rate Measurement}

The flocculating rate was measured using a previous method with a slight modification, in which Kaolin clay was chosen as the suspended solid (Kurane R., 1986). Kaolin clay was suspended in distilled water at the concentration of $5000 \mathrm{mg} / \mathrm{L}$. $4.50 \mathrm{~mL}$ of $1 \% \mathrm{CaCl} 2$ and $0.5 \mathrm{~mL}$ of culture broth were added to $45 \mathrm{~mL}$ Kaolin suspended solution in 100 $\mathrm{mL}$ beaker in turn. The mixture was vigorously stirred and was allowed to stand for 5 minutes. The optical density (OD) of the clarifying solution (A) was measured with a spectrophotometer at $550 \mathrm{~nm}$. A control experiment was prepared using the same method, but the culture broth was replaced by distilled water (B). The flocculating activity was calculated according to the equation:

$$
\text { Flocculating activity }(\%)=\{(B-A) / B\} \times 100)
$$

Where:

A: is the optical density of the sample experiment at $550 \mathrm{~nm}$

B: is the optical density of control experiment at $550 \mathrm{~nm}$

Effects of $\mathrm{pH}$, flocculant's concentration, and various actions on flocculation were investigated. Two sets (A and B) of 5 conical flasks were taken. $10 \mathrm{ml}$ of dye wastewater was taken in each flask of set A whereas $10 \mathrm{ml}$ distilled water was added to each flask of set B. A control flask was prepared using the same method but the sample was replaced by distilled water flocculating activity was measured by 5 conical flask as controlling group and another 5 conical flask as dye wastewater which was taken every 2 hours at different temperatures 


\subsection{Preparation of dye wastewater}

The dye concentrations were adjusted to be $20,50,100$ and $150 \mathrm{mg} / \mathrm{L}$ in the reactors $\mathrm{R} 1, \mathrm{R} 2, \mathrm{R} 3$ and $\mathrm{R} 4$ and were determined for COD and MLVSS every day.

\section{Results and discussion}

\subsection{Bioflocculant-producing properties}

The bacteria was in the highest flocculation of Kaolin suspension attained was $98 \%$. The same phenomenon happens where the flocculating activity paralleled the growth of the microorganism.

\subsection{Effect of time on the flocculating rate}

Based on the preceding results, the flocculants activity measurements at after every 2 hours and at different temperatures are employed. Durations of incubation period are number1: first two hours, number 2: second two hours, number 3: third two hours and etc. For example at $35^{\circ} \mathrm{C}, 40^{\circ} \mathrm{C}$ and $45^{\circ} \mathrm{C}$ as illustrated below in figure 1, will show that flocculants activity will increase along the time periods.

Figure1: the effect of different incubation periods on flocculent rates at temperature $35^{\circ} \mathrm{C}$

Figure 1, shows the flocculants activity with different time percentage of absorbance for dye wastewater more than control the flocculation mirrored the growth of the biomass and increased with time every two hours, the bacteria was in its exponential growth phase, because control include bacteria and distilled water and dye wastewater include Cibacron yellow FN_2R and bacteria result shows that bacteria more growth in dye wastewater and the flocculation also rapidly increased the highest flocculation of kaolin suspension attained was $98.4 \%$ at $35^{\circ} \mathrm{C}$ as shown in Figure 1.

Figure 2: the effect of different incubation periods on flocculent rates at temperature $40^{\circ} \mathrm{C}$

Figure 3: the effect of different incubation periods on flocculent rates at temperature $45^{\circ} \mathrm{C}$

Figure 2 and 3, show that at $40^{\circ} \mathrm{C}$ and $45^{\circ} \mathrm{C}$ flocculating efficiency was lowest amount and the flocculation of kaolin suspension attained was $82 \%$ at $45^{\circ} \mathrm{C}$. The decreasing in flocculation rate could be due to thermal effect (Wu J. Y., 2007). Structure of bioflocculant would be destroyed while heating, hence the bioflocculants are considered thermally unstable.

\subsection{Effect of HRT on COD and MLVSS}

Figure 4 and 5, show that between different concentration of dye wastewater for 20,50, 100 and $150 \mathrm{mg} / \mathrm{L}$ every $24 \mathrm{~h}$, COD decrease and MLVSS increase.

Figure 4: Effect of HRT on COD (HRT=1day)

Determination of MLVSS in different concentration of dye (figure 5) show that during period as time pass, we have increase in MLVSS (HRT $=24 \mathrm{~h}$ ). This results shows that bacteria growth during the time (Ilgi Karapinar Kapdan, 2006).

Figure 5: Effect of HRT on MLVSS (HRT=1day)

In figure 5, the first MLVSS was varied from low concentration to high concentration. This behavior could be result of the saturation of available colloidal surface with the attached EPS chemical bridge. Furthermore, production of EPS and bacteria gradually increase with time.

\section{Conclusion}

Flocculation processes gave satisfactory results. The results show that the optimal flocculant quantity has to be used. The bioflocculant production was found to considerably depend on the culture temperature. Various culture temperatures were tested between 2 hours in order to investigate their effect on the bioflocculant production when the culture temperature was $35^{\circ} \mathrm{C}$ where the flocculating activity of Sphingomonas paucimobilis was up to $98.4 \%$ and when the culture temperature was $45^{\circ} \mathrm{C}$ the flocculating activity was in lower amount. The best temperature was found be for production this bacteria is $35^{\circ} \mathrm{C}$. A bioflocculant produced by Sphingomonas paucimobilis was effective for the removal of dye. Cibacron yellow FN_2R is one of the main dyes that are used in textile industries in Malaysia. Therefore, industrial effluents containing dyes must be treated before their discharge into the environment (Wong Pei Wen, 2003) and Closed Drainage System (CDS) located in Prai industrial areas was selected as microbial source. CDS served a major industrial zone in Prai where heavy industries such as chemical process, petrochemical and heavy metal are located. Selected Sphingomonas paucimobilis isolated from (CDS) and Cibacron yellow FN_2R as dye wastewater because it was reactive dye wastewater. Reactive wastewater and reactive dyes are more frequently used in dyeing processes due to their good solubility in water. Counting bacteria and determination flocculating activity was shown Sphingomonas paucimobilis is biodegradable and increase in number of bacteria during the time will confirm that. Results show that time and a temperature effect on growth of bacteria is effective. This study was using sequencing batch reactor (SBR) technology at different concentrations of dye wastewater between every day (HRT $=1$ day) 
bacteria growth and produce biopolymer every day and decrease COD, increase MLVSS. Its practical application in industry would also be developed in further progress.

\section{Acknowledgement}

The authors are grateful to the Institute of postgraduate studies (IPS), Univesiti Sains Malaysia for outstanding support of this research.

\section{Reference}

A.S. Özcan, B. Erdem and A. Özcan. (2005). Adsorption of Acid Blue 193 from aqueous solutions onto BTMAbentonite, Colloid Surf. Engineering Aspecta, 266, p.73-81.

B.H. Tan, T.T. Teng and A.K.M. Omar. (2000). Color removal from dye. Water Research, 34, p. 597-601

C. Allegre, M. Maisseu, F. Charbit and P. Moulin. (2004). Coagulation-flocculation-decantation of dye house effluents: concentrated effluents. Journal of Hazardous Materials, 116, p. 57-64.

D. Georgiou, A. Aivazidis, J. Hatiras and K. Gimouhopoulos. (2003). Treatment of cotton textile wastewater using lime and ferrous sulphate. Water Research. 37, p. 2248-2250.

Fujita M., Ike M., Tachibana S., Kitada G., Kim S. M. and Inoue Z. (2000). Characterization of a bioflocculant produced by Citrobacter sp. TKF04 from acetic and propionic acids. Journal of Bioscience and Bioengineering, 89(1), p.40-46.

Garcia-Montano J., Torrades F., Garcia-Hortal J.A., Domenech J., and Peral J. (2006. Degradation of Porcion Red HE7B reactive dye by coupling a photo-Fenton system with a sequencing batch reactor. Journal of Hazardous Materials, 134, p. 220-229.

H. Yokoi, T. Yoshida, S. Mori, J. Hirose, S. Hayashi and Y. Takasaki. (1997). Biopolymer flocculant produced by an Enterobacter sp. Journal of Biotechnology Letters. 19(6), p. 569-573.

Ilgi Karapinar Kapdan and Rukiye Oztekin. (2006). The effect of hydraulic residence time and initial COD concentration on color and COD removal performance of the anaerobic-aerobic SBR system. Journal of Hazardous Material. 136, p. 896-901

J. Roussy, P. Chastellan, M. van Vooren and E. Guibal. (2005). Treatment of ink-containing wastewater by coagulation/flocculation using biopolymers. Water SA, 31, p. 369-376.

J.H. Choi, W.S. Shin, S.H. Lee, D.J. Joo, J.D. Lee, S.J. Choi and L.S. Park. (2001). Corynebacterium glutamicum: a proposed biosynthetic pathway. Science and Technology, 36, p. 2945-2958.

K. Kakii, E. Sugahara and T. Shirakashi. (1986). Isolation and characterization of Ca-dependent floc-forming bacterium. Journal of Fermenting Bioengineering, 41, p. 57-62.

Kapdan, I. K., Ozturk, R. (2005). Effect of operating parameters on color and COD removal performance of SBR: Sludge age and initial dyestuff concentration. Journal of Hazardous Materials, 123, p. 217-222.

Kurane R., Takeda, K. and Suzuki T. (1986). Screening for and characteristics of microbial flocculants. Journal of Agriculture and Biology Chemistry, 50, p. 2301-2307

Lee C., Wang C., Juang L., Lyu M., H. Hung and S. Liu. (2008). Effects of sodium content on the microstructures and basic dye action exchange of titanate nanotubes, Colloid Surf. Engineering Aspects, 317, p. 164-173.

Li Y., He N., Guan H., Du G. and Chen J. (1999). A novel polygalacturonic acid bioflocculant REA-11 produced by Corynebacterium glutamicum: a proposed biosynthetic pathway and experimental confirmation. Journal of Environmental Management, 12, p.351-355.

M. Zhou and J. He. (2007). Degradation of azo dye by three clean advanced oxidation processes: Wet oxidation, electrochemical oxidation and wet electrochemical oxidationa comparative study. Electrochim. Acta, 53, p. 1902-1910.

S. B. Deng, R.B. Bai, X.M. Hu and Q. Luo. (2003). Characteristics of a bioflocculant produced by Bacillus mucilaginosus and its use in starch wastewater treatment. Agricultural Biology Chemistry 60, p. 588-593

T. Endo, K. Nakaruma and H. Takahshi. (1976). Pronas susceptible floc-forming bacteria. Journal of Agriculture and Biology Chemistry, 40, p. 2289-2295.

V. Golob, A. Vinder and M. Simonič. (2005). Efficiency of the coagulation/flocculation method for the treatment of dyebath effluents. Dyes Pigments, 67, p. 93-97.

W. Zhu, Z. Yang and L. Wang. (2001). Application of ferrous hydrogen peroxide for treatment of DSD-acid manufacturing process wastewater. Water Research, 35, p. 2087-2091. 
Wong Pei Wen, Teng joon Tow, Zuraidoh Moht and L. Zain, M. Z. (2003). Removal of Disperse Dye and Reactive Dye by Coagulation-Flocculation Method. Processing of Environmental conference, 2, p. 264-269

Wu J. Y. and Ye H. F. (2007). Characterization and flocculating properties of an extra cellular biopolymer produced from a Bacillus subtilis DYU 1 isolate. Processing of biochemistry conference, 42, p. 1114-1123.

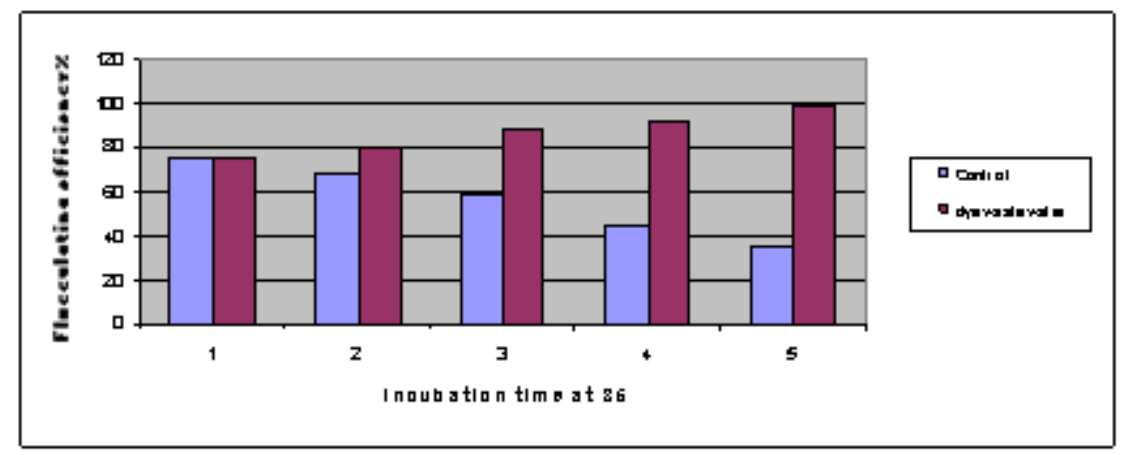

Figure 1. The effect of different incubation periods on flocculent rates at temperature $35^{\circ} \mathrm{C}$

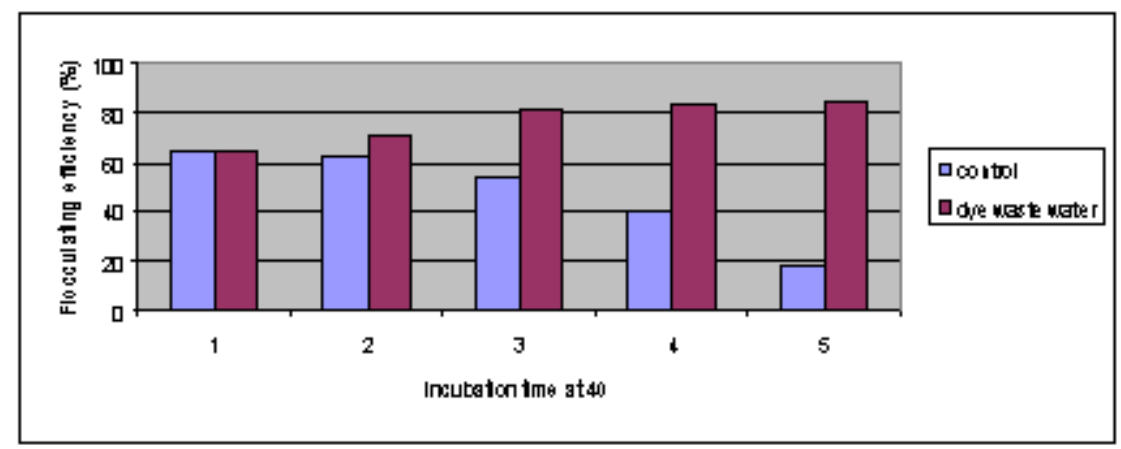

Figure 2. The effect of different incubation periods on flocculent rates at temperature $40{ }^{\circ} \mathrm{C}$



Figure 3. The effect of different incubation periods on flocculent rates at temperature $45^{\circ} \mathrm{C}$ 


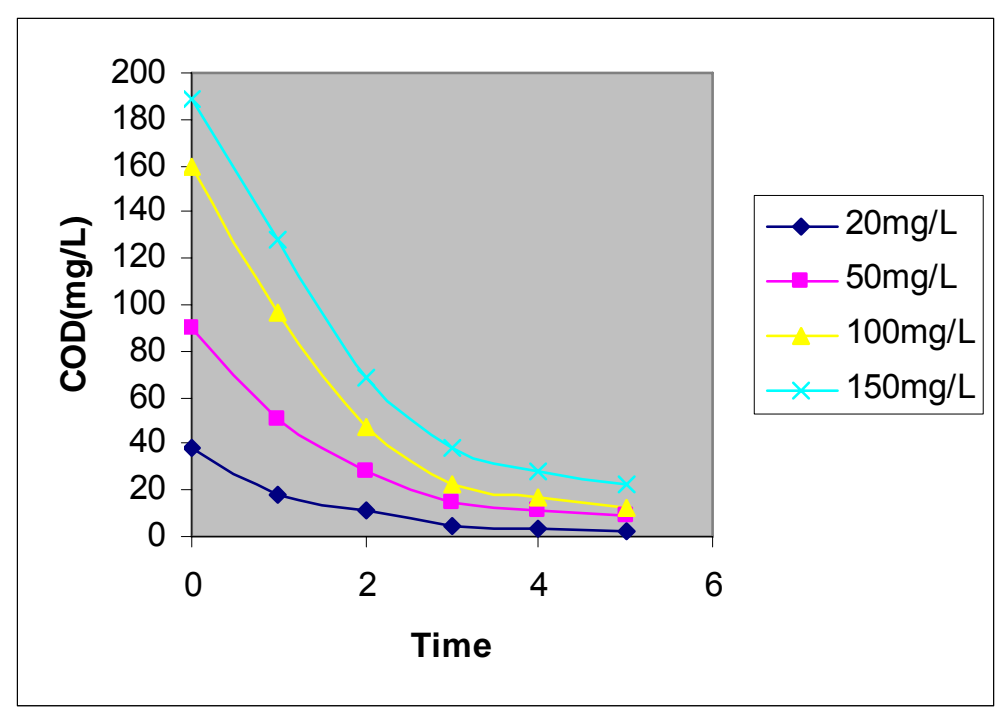

Figure 4. Effect of HRT on COD (HRT=1day)

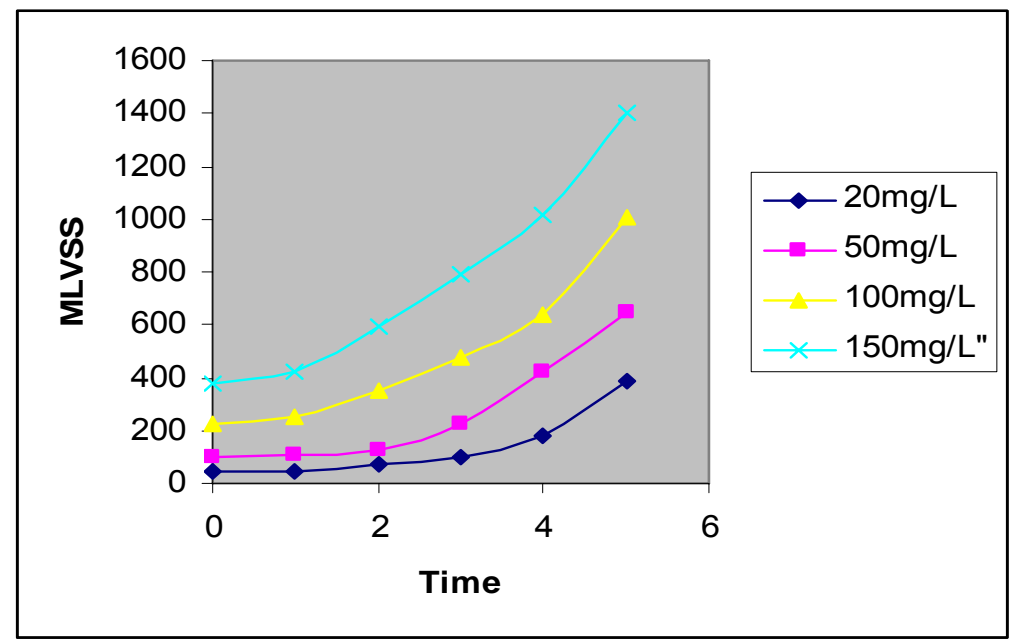

Figure 5. Effect of HRT on MLVSS (HRT=1day) 